\title{
Assessing Soil Fertility Status of Rehabilitated Degraded Tropical Rainforest
}

\author{
${ }^{1}$ Aiza Shaliha Jamaluddin, ${ }^{1,3}$ Arifin Abdu, ${ }^{1,3}$ Hazandy Abdul-Hamid, \\ ${ }^{1}$ Mohd Hadi Akbar, ${ }^{1}$ Trevor Saga Banga, ${ }^{2}$ Shamshuddin Jusop and ${ }^{3}$ Nik Muhamad Majid \\ ${ }^{1}$ Department of Forest Management, Faculty of Forestry, \\ ${ }^{2}$ Department of Land Management, Faculty of Agriculture, \\ ${ }^{3}$ Institute of Tropical Forestry and Forest Products, \\ Universiti Putra Malaysia, 43400 UPM Serdang, Selangor, Malaysia
}

Received 2013-01-09, Revised 2013-04-13; Accepted 2013-07-19

\begin{abstract}
An assessment of forest rehabilitation program in relation to soil fertility status by using soil indices could provide fundamental information on soil suitability for species preferences and improve the effective technique for future rehabilitation program in tropical rainforests. This study was conducted in order to characterize the soil properties and identifying the soil fertility status of rehabilitated and secondary forests. Soil samples were collected in year 2009 at rehabilitation forests (20 years after planting) and secondary forest of Nirwana Forest Reserve, Universiti Putra Malaysia (UPM) Bintulu Campus, Sarawak, Malaysia. The rehabilitation plots were planted with mixed dipterocarp and non-dipterocarp species since 1991. Prior to conversion of the areas into various land use types, the rehabilitation and secondary forests areas were considered as natural forests and subsequently subjected to forest logging with Selective Management System (SMS) in 1980s. The plot size for each site was $20 \times 20 \mathrm{~m}$ for 18 experimental sites (at different ages after planting) were established, followed by soil sampling at $0-15 \mathrm{~cm}$ and $15-30 \mathrm{~cm}$ depth randomly using soil auger. Standard soil analysis for physical and chemical properties was used to analyze the soil samples. The soil fertility status was evaluated using two indices, namely Soil Fertility Index (SFI) and Soil Evaluation Factor (SEF) for both rehabilitated and secondary forests. The results showed that there were significant differences $(\mathrm{p}<0.05)$ in $\mathrm{pH}$ (water and $\mathrm{KCl}$ ), exchangeable $\mathrm{Mg}, \mathrm{Na}, \mathrm{Al}$ and ammonium and granule composition (clay, silt and sand) between depths. The PCA result of $70 \%$ total variability (OM, TOC, TC and CEC) score in PC1 shows positive relationship, explaining nutrients in the soil stored in the organic matter in the surface soils. The correlation analysis indicated that there were positive relationship $(\mathrm{p}<0.05)$ between $\mathrm{OM}$ and TC, CEC and exchangeable Al for surface soils. We found that the selected physico-chemical properties had a significant differences based on the age of planting of rehabilitated forests. For subsurface soils, correlation between exchangeable $\mathrm{Al}$ and $\mathrm{OM}$ and CEC shows strong positive relationship, indicating that negative charge derived from organic materials plays important roles for cation retention capacity. The SFI and SEF for rehabilitation forests showed higher value as compared to secondary forests, indicating forest rehabilitation had improved the soil fertility status of degraded forestland. In conclusion, both rehabilitated and secondary forests have significant differences based on the selected physical and chemical properties. Moreover, the soil fertility status at rehabilitated plots was higher than secondary forest, which is proved that the forest rehabilitation technique is a suitable planting technique for rehabilitating and replenishing soil fertility status of abandoned degraded shifting cultivation land.
\end{abstract}

Keywords: Rehabilitated Forest, Secondary Forest, Physical and Chemical Properties, Soil Fertility, SFI and SEF indices

Corresponding Author: Arifin Abdu, Department of Forest Management, Faculty of Forestry, Universiti Putra Malaysia, 43400 UPM Serdang, Selangor, Malaysia Tel: +603-89467177 Fax: +603-89432514 


\section{INTRODUCTION}

Tropical rainforest of Malaysia is considered as one of the most important for maintaining global climate change worldwide (Arifin et al., 2008a). These forests consist of unique and complex ecosystems which are home to the country's rich flora and fauna. Tropical forest area is disappearing at the rate of 13.5 million ha per year, mainly due to clearing for plantation or agriculture and shifting cultivation (Daljit et al., 2011). According to FAO (2010), Malaysia's total forest area decreased by 434000 hectares between 2005 and 2010 (an annual decline of $0.42 \%$ ) and by 1.92 million hectares between 1990 and 2010 of the estimated 17.1 million hectares of dry inland forests, 5.48 million hectares are in Peninsular Malaysia, 7.83 million hectares are in Sarawak and 3.84 million hectares are in Sabah (ITTO, 2011). In Sarawak, besides forest harvesting and forest encroachment, shifting cultivation is the major cause of land degradation. It was reported that 2.25 million ha were under shifting cultivation in the 1960s and by 1985 increased to 3.33 million ha (ITTO, 2011).

Deforestation of tropical forest could affect global warming by accelerating the greenhouse gases emission and increasing the accumulation of $\mathrm{CO}_{2}$ as a result of photosynthesis (Kobayashi, 1994). Tropical forests have the largest potential to mitigate climate change amongst the world's forest through conservation of existing $C$ pools through the establishment of forest plantations and agroforestry program (Brown et al., 1989). Grainger (1993) stated that deforestation exposes soil to erosion and to four other forms of degradation such as fertility depletion, compaction and landslides. The effect of soil degradation becomes apparent locally, resulting in low productivity and sustainability of farming on degraded soils (Grainger, 1993).

Several researchers have proved that in order to overcome degraded forest land into more productive areas, plantation forest or rehabilitation activities areconsiderate an important tool from a global perspective in terms of wood and ecosystem resources and eco-friendly environment services (Arifin et al., 2008a; 2008b; Cole et al., 1996; MacNamara et al., 2006). In addition, forest rehabilitation also attempts to return the forest to a stable and productive condition in terms of soil fertility status, but not necessarily the original diversity, structure and function. Forest rehabilitation of rainforest is often undertaken with two primary reasons which are to restore the ecology stability for facilities, biological and chemical improvement of degraded sites and to restore productivity of degraded sites in order to gain economic returns through agriculture or forestry which commonly involves plantation of native and exotic species on degraded forest land (Lamb and Olsen, 1992). One technique has been carried out in Bintulu, Sarawak using mixed dense planting method for rehabilitating degraded shifting cultivation area (Miyawaki, 2010). The indigenous tree species recommended were Shoreaovata, S. macrophylla, S. mecistopteryx, Dryobalanops aromatica, Parashorea parvifolia, Hopea beccariana, Durio carinatus and Eusideroxylon zwagery (Alias et al., 1998).

Forest rehabilitation activity on degraded tropical rainforest should emphasize on the ecosystem involving soil properties, soil fertility and species selection for the progress of rehabilitation techniques in the future (Arifin et al., 2008a). The progress of rehabilitation program under tropical conditions has been reported by several researchers (Arifin et al., 2008b; Cole et al., 1996; MacNamara et al., 2006; Tilki and Fisher, 1998; Norisada et al., 2005). Most works have focused on species selection for planting proposes in relation to the growth productivity at degraded forest, assessing soil fertility status under rehabilitation program at degraded forest of more than 16 years after planting in Malaysia are still limited and even lacking.

Therefore, preliminary assessment of rehabilitation program in relation to soil fertility status using soil indices could provide information on soil suitability for species preferences and improve effective technique for future rehabilitation program. The objective of this study was to characterize the soil properties and identifying the soil fertility status of rehabilitated and secondary forests using soil Fertility Index (SFI) and Soil Evaluation Factor (SEF). The SFI (Moran et al., 2000) and SEF (Lu et al., 2002) are recently recommended methods used for evaluating soil fertility and productivity of succession of secondary forest in humid tropical region (Arifin et al., 2008a).

\section{MATERIALS AND METHODS}

\subsection{Background and Location of the Study Area}

This study was carried out in a forest under rehabilitation (UPM-Mitsubishi Corporation plot) and secondary forest (Nirwana Forest Reserve) at Universiti Putra Malaysia Bintulu Campus in Sarawak, Malaysia (Fig. 1). The area is originally covered by natural tropical forest since immemorial time. The common species present are dipterocarp (Dipterocarp spp, Shorea parvifolia, Shorea leprosula and Hopea spp) and non-dipterocarp (Syzygium spp, Mallotus leucodermis, Macaranga gigantea and Pometia pinnata). Prior to the project, the site was an abandoned land after shifting cultivation. 


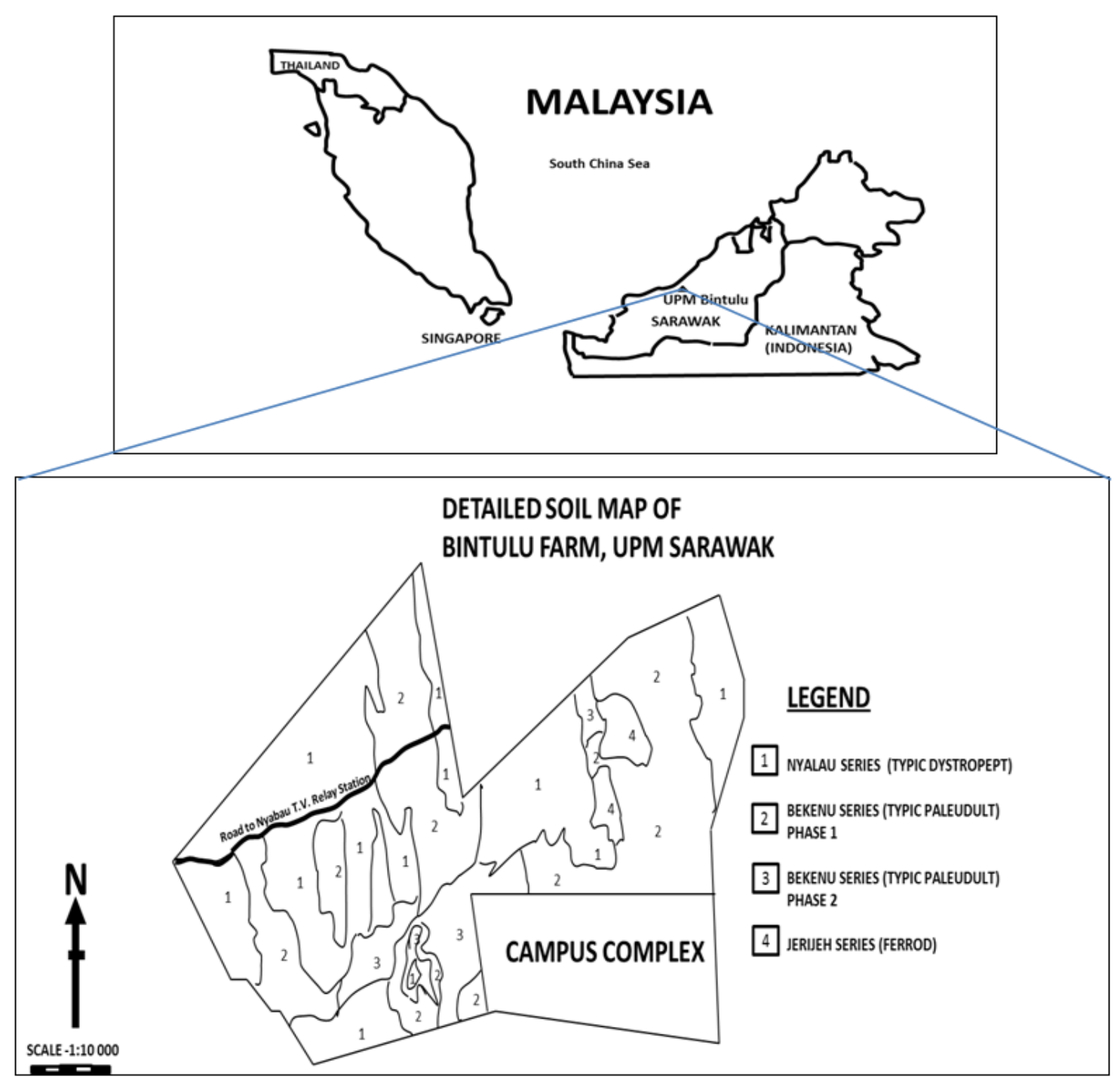

Fig. 1. Detailed soil map of UPM Bintulu Campus, Sarawak (modified from Mat et al., 1984)

The rehabilitated forest (Malaysia Tropical Forest Regeneration Experimental Project) initially a joint research project between Yokohama National University and Universiti Putra Malaysia was sponsored by Mitsubishi Corporation in 1990. Among the species planted in the rehabilitated forest are Shorea macrophylla, $S$. pinanga, S. spelendica, $S$. palembanica, S. ovata, S. streoptera, Dryobalanops aromatica and Hopea spp. It is situated about 10 kilometer along Bintulu-Miri Road in the state of Sarawak, Malaysia (latitude $3^{\circ} 12^{\prime} \mathrm{N}$ and longitude $\left.113^{\circ} 05^{\prime} \mathrm{E}\right)$. The terrain of the area is highly dissected with a small stream cutting across the campus, draining rainwater into the nearby sea.

In contrast, the secondary forest (Nirvana Forest Reserve) was a logged-over in 1980s and left idles without any forest management. The common trees species found during the site survey and soil sampling at secondary forest were dipterocarp (Shorea spp. and Hopea spp.) and non-dipterocarp species (Macaranga spp and Mallotus spp). The height and Diameter at Breast Height (DBH) of dipterocarp and nondipteroarcarp species ranged approximately from 5-25 m and $5-30 \mathrm{~cm}$, respectively. 
The soils at the sites belong to Berkenu and Nyalau series of Ultisols order (Mat et al., 1984). The area under study is covered by the rocks of Nyalau Formation of Miocene age (5-20 million years old), which are composed of moderately hard sandstone occasionally intercalated with shale; the sandstone contained mainly quartz with 10-15\% feldspars. Other minor minerals are muscovite, biotite and iron ores. This area has been exposed to wet and dry condition throughout the year for a long period of time. Monthly rainfall is in excess of $200 \mathrm{~mm}$ and the annual rainfall is about $3770 \mathrm{~mm}$; higher rainfall occurs in the months of October, November and December (Mat et al., 1984). The mean maximum temperature is $>40^{\circ} \mathrm{C}$, while the mean minimum is $22^{\circ} \mathrm{C}$; the average mean temperature is therefore above $30^{\circ} \mathrm{C}$.

\subsection{Soil Sampling and Analysis}

Sixteen plots of rehabilitated forest were set up (planting year 1991 to 2008, no planting in year 1992 and 1994) and two plots in secondary forestwere used as the control plots in order to compare the physicochemical properties and soil fertility status. The plot size for each site was $20 \times 20 \mathrm{~m}$. Each plot was divided into two subplots. Soil samples were collected at two depths, surface $(0-15 \mathrm{~cm})$ and subsurface $(15-30 \mathrm{~cm})$ from each corner and in the middle of the plotusing soil auger and homogenized to make a composite sample. The samples were air-dried, homogenized and sieved to pass a $2 \mathrm{~mm}$ mesh sieve for physical and chemical analyses.

Particle-size distribution was determined using the pipette methods (Gee and Bauder, 1986). Soil $\mathrm{pH}$ was determined in water and $1 \mathrm{M} \mathrm{KCl}$ in a soil to solution ratio of 1: 2.5 using glass electrodes after reciprocal shaking for 1 hour. The exchangeable acidity and exchangeable aluminum were extracted once with $1 \mathrm{M}$ $\mathrm{KCl}$. The exchangeable acidity was determined by the titration method using $0.01 \mathrm{M} \mathrm{NaOH}$ and the content of exchangeable $\mathrm{Al}$ with $0.01 \mathrm{M} \mathrm{HCl}$ (Sumner and Stewart, 1992). Organic matter and total organic carbon were determined using loss-on-ignition method (Banning et al., 2008). Total nitrogen was determined using Kjeldahl method (Bremner and Mulvaney, 1982) and total carbon in soil was determined using LECO-412 machine. Available phosphorus was determined by the Bray II method (Kuo, 1996). Exchangeable cations (K, Ca, Mg and $\mathrm{Na}$ ) were extracted with $1 \mathrm{M} \mathrm{NH}_{4} \mathrm{OA}_{\mathrm{c}}$ buffered at $\mathrm{pH}$ 7. The concentration of $\mathrm{K}, \mathrm{Ca}, \mathrm{Mg}$ and $\mathrm{Na}$ in the solutions was measured by AAS (Shimadzu AA-6800). Cation Exchange Capacity (CEC) was determined by $0.05 \mathrm{M} \mathrm{K}_{2} \mathrm{SO}_{4}$ using the soil used for the basic exchangeable cation determination.

\subsection{Data Analysis}

We performed an independent t-test to detect any significant differences on the surface soils $(0-15 \mathrm{~cm})$ and subsurface soil $(15-30 \mathrm{~cm})$ for rehabilitated forest secondary forest. Analysis of Variance (ANOVA) was used to detect any significance differences of physicochemical properties of different ages of forest after planting. Post-hoc test Tukey's (HSD) were used to detect significant differenceat rehabilitated sites. Principal Component Analysis (PCA) was performed to detect the most prominent soil parameters that influence the fertility of the soil. The relationship between the selected soil parameter was determined using Pearson's correlation analysis. The Statistical Analysis System (SAS) version 9.1 was used for the statistical analysis. Soil Fertility Index (SFI) (Moran et al., 2000) and Soil Evaluation Factor (SEF) (Lu et al., 2002) were used to evaluate the soil fertility both at rehabilitated and secondary forests. The SFI and SEF indices were calculated to quantify the intensity of land degradation in the study area based on the following equations:

$\mathrm{SFI}=\mathrm{pH}+$ Organic matter $(\%$ dry soil basis $)+$ Available P ( $\mathrm{mg} \mathrm{kg}^{-1}$ dry soil $)+$ Exchg. $\mathrm{K}\left(\mathrm{cmol}_{\mathrm{c}} \mathrm{kg}^{-1}\right)+$ Exchg.Ca $\left(\mathrm{cmol}_{\mathrm{c}} \mathrm{kg}^{-1}\right)+$ Exchg. $\mathrm{Mg}\left(\mathrm{cmol}_{\mathrm{c}} \mathrm{kg}^{-1}\right)-$ Exchg. $\mathrm{Al}\left(\mathrm{cmol}_{\mathrm{c}} \mathrm{kg}^{-1}\right)$

$\mathrm{SEF}=\left[\right.$ Exchg. $\mathrm{K}\left(\mathrm{cmol}_{\mathrm{c}} \mathrm{kg}^{-1}\right)+$ Exchg. $\mathrm{Ca}\left(\mathrm{cmol}_{\mathrm{c}} \mathrm{kg}^{-1}\right)+$ Exchg Mg $\left(\mathrm{cmol}_{\mathrm{c}} \mathrm{kg}^{-1}\right)-\log \left(1+\right.$ Exchg. $\left.\mathrm{Al}\left(\mathrm{cmol}_{\mathrm{c}} \mathrm{kg}^{-1}\right)\right]$ $\mathrm{x}$ Organic matter $(\%$ dry soil basis $)+5$.

Both indices (SFI and SEF) were developed and used to assess the soil biomass and fertility status under succession of secondary forest in the Amazon humid tropical forest of Brazil. The suitability of SFI and SEF indices were used in the present study to determine the soil fertility between rehabilitated and secondary forests.

\section{RESULTS AND DISCUSSION}

\subsection{Characterizing Soil Properties at Rehabilitated and Secondary Forests}

The average values of the physico-chemical properties for surface and subsurface soils are presented in Table 1a and $\mathbf{b}$. The textural class of the soils in the study area is fine loamy. The clay content of surface soils was lower than that of the subsurface soils. It ranged from 15.85 to $26.04 \%$ in the surface $(0-15 \mathrm{~cm})$ and 19.03 and $29.62 \%$ in the subsurface soils $(15-30$ 
$\mathrm{cm})$. The clay and silt contents for the surface soils for rehabilitated forests was significantly higher $(\mathrm{p}<0.05)$ than those of the secondary forests. On the other hand, the sand fraction of the surface soils for secondary forests was significantly higher $(\mathrm{p}<0.05)$ than rehabilitated forests. The soils at the sites belong to the Berkenu and Nyalau Series
(Ultisols). Bekenu Series could be classified as fine loamy, mixed, isohyperthermic family of Typic Paleudult (Mat et al., 1984). Paramananthan (2000) stated that Bekenu Series is a low fertility soil as it is highly weathered. The Nyalau series can be classified as coarse loamy, kaolinitic, isohyperthermic family of Typic Dystropept.

Table 1a. Soil physico-chemical properties at rehabilitated forest and secondary forest for surface soil $(0-15 \mathrm{~cm})$

\begin{tabular}{|c|c|c|c|c|c|c|c|c|c|c|c|c|c|c|}
\hline \multirow{2}{*}{$\begin{array}{l}\text { Plots/ } \\
\text { Years }\end{array}$} & \multirow[b]{2}{*}{$\mathrm{pH}_{\mathrm{k}}$} & \multirow[b]{2}{*}{$\mathrm{pH}_{\mathrm{w}}$} & \multirow{2}{*}{$\begin{array}{l}\text { OM } \\
(\%)\end{array}$} & \multicolumn{2}{|c|}{$\left(\mathrm{g} \mathrm{kg}^{-1}\right)$} & \multirow[b]{2}{*}{$\mathrm{CEC}$} & \multicolumn{4}{|c|}{ Exchangeable cation $\mathrm{cmol}_{\mathrm{c}} \mathrm{kg}^{-1}$} & \multirow{2}{*}{$\begin{array}{l}\text { Av. P } \\
(\mathrm{ppm})\end{array}$} & \multicolumn{3}{|c|}{ Granule composition (\%) } \\
\hline & & & & $\mathrm{T}-\mathrm{C}$ & $\mathrm{T}-\mathrm{N}$ & & K & $\mathrm{Ca}$ & $\mathrm{Mg}$ & $\mathrm{Al}$ & & llay & Silt & Sand \\
\hline 1991 & $3.65^{\mathrm{de}}$ & $4.53^{\mathrm{abc}}$ & $5.54^{\mathrm{abc}}$ & $1.62^{\mathrm{ab}}$ & $2.04^{\mathrm{a}}$ & $6.70^{\mathrm{abc}}$ & $0.18^{\mathrm{a}}$ & $0.33^{\mathrm{a}}$ & $0.27^{\mathrm{a}}$ & $10.35^{\mathrm{abc}}$ & $3.63^{\mathrm{a}}$ & $20.23^{\mathrm{abc}}$ & $40.05^{\mathrm{a}}$ & $39.52^{\mathrm{d}}$ \\
\hline 1993 & $3.65^{\mathrm{de}}$ & $4.34^{\mathrm{bc}}$ & $4.75^{\mathrm{bc}}$ & $1.80^{\mathrm{ab}}$ & $2.42^{\mathrm{a}}$ & $3.85^{\mathrm{abc}}$ & $0.15^{\mathrm{a}}$ & $0.22^{\mathrm{a}}$ & $0.21^{\mathrm{bc}}$ & $7.90^{\text {abcd }}$ & $1.74^{\mathrm{a}}$ & $21.90^{\mathrm{abc}}$ & $38.61^{\mathrm{a}}$ & $39.50^{\mathrm{d}}$ \\
\hline 1995 & $3.92^{\mathrm{ab}}$ & $4.81^{\mathrm{ab}}$ & $5.08^{\mathrm{abc}}$ & $1.62^{\mathrm{ab}}$ & $2.38^{\mathrm{a}}$ & $8.15^{\text {abc }}$ & $0.11^{\mathrm{ab}}$ & $0.09^{\mathrm{a}}$ & $0.11^{\mathrm{abc}}$ & $7.45^{\text {abcd }}$ & $1.89^{\mathrm{a}}$ & $17.32^{\mathrm{bc}}$ & $41.44^{\mathrm{a}}$ & \\
\hline 1996 & $3.99^{\mathrm{a}}$ & $4.97^{\mathrm{a}}$ & $3.84^{\mathrm{bc}}$ & $1.74^{\mathrm{ab}}$ & $2.67^{\mathrm{a}}$ & $3.80^{\mathrm{abc}}$ & $0.11^{\mathrm{ab}}$ & $0.08^{\mathrm{a}}$ & $0.08^{\mathrm{cd}}$ & $5.15^{\mathrm{de}}$ & $2.22^{\mathrm{a}}$ & $19.49^{a b c}$ & $36.94^{\mathrm{ab}}$ & $43.58^{\mathrm{cd}}$ \\
\hline 1997 & $3.86^{\mathrm{abcd}}$ & $4.66^{\mathrm{abc}}$ & $4.66^{\mathrm{bc}}$ & $1.68^{\mathrm{b}}$ & $3.17^{\mathrm{a}}$ & $9.25^{\mathrm{abc}}$ & $0.11^{\mathrm{ab}}$ & $0.05^{\mathrm{a}}$ & $0.10^{\text {bcd }}$ & $6.65^{\text {bcde }}$ & $2.26^{\mathrm{a}}$ & $26.12^{\mathrm{a}}$ & $33.67^{\mathrm{abc}}$ & $2^{d}$ \\
\hline 1998 & $3.85^{\mathrm{abcd}}$ & $4.61^{\mathrm{abc}}$ & $5.25^{\mathrm{abc}}$ & $1.43^{\mathrm{ab}}$ & $2.17^{\mathrm{a}}$ & $7.75^{\mathrm{bc}}$ & $0.09^{\mathrm{ab}}$ & $0.09^{\mathrm{a}}$ & $0.05^{\mathrm{d}}$ & $7.30^{\text {bcde }}$ & $2.25^{\mathrm{a}}$ & $25.06^{\mathrm{ab}}$ & $32.66^{\mathrm{abc}}$ & 42 \\
\hline 1999 & $3.80^{\mathrm{abcd}}$ & $4.53^{\mathrm{abc}}$ & $5.21^{\mathrm{abc}}$ & $2.20^{\mathrm{ab}}$ & $2.12^{\mathrm{a}}$ & $6.85^{\mathrm{abc}}$ & $0.11^{\mathrm{ab}}$ & $0.08^{\mathrm{a}}$ & $0.12^{\text {bcd }}$ & $7.30^{\text {bcde }}$ & $2.63^{\mathrm{a}}$ & $18.51^{\mathrm{abc}}$ & $25.72^{\text {bcd }}$ & $55.78^{\mathrm{abc}}$ \\
\hline 2000 & $3.88^{\mathrm{abc}}$ & $4.78^{\mathrm{ab}}$ & $4.31^{b c}$ & $1.92^{\mathrm{ab}}$ & $2.21^{\mathrm{a}}$ & $7.60^{\mathrm{abc}}$ & $0.14^{\mathrm{ab}}$ & $0.08^{\mathrm{a}}$ & $0.12^{\mathrm{bcd}}$ & $7.80^{\text {abcde }}$ & & & $33.57^{\mathrm{abc}}$ & \\
\hline 2001 & $3.87^{\mathrm{abc}}$ & $4.85^{\mathrm{ab}}$ & $4.68^{b c}$ & $1.61^{\mathrm{ab}}$ & $2.03^{\mathrm{a}}$ & $1.85^{\mathrm{bc}}$ & $0.08^{\mathrm{ab}}$ & $0.05^{\mathrm{a}}$ & $0.04^{\mathrm{d}}$ & $5.50^{\text {cde }}$ & $3.49^{\mathrm{a}}$ & $19.93^{a b c}$ & $34.15^{\mathrm{ab}}$ & $45.92^{\mathrm{cd}}$ \\
\hline 2002 & & & $7.84^{\mathrm{a}}$ & $2.58^{\mathrm{a}}$ & $3.61^{\mathrm{a}}$ & & $0.12^{\mathrm{ab}}$ & & & $12.30^{\mathrm{a}}$ & & $18.96^{\mathrm{abc}}$ & $38.67^{\mathrm{a}}$ & $8^{\mathrm{cd}}$ \\
\hline 2003 & $3.74^{\text {bcd }}$ & $4.69^{\mathrm{ab}}$ & $6.42^{\mathrm{ab}}$ & $1.89^{\mathrm{ab}}$ & $1.59^{\mathrm{a}}$ & $12.55^{\mathrm{ab}}$ & $0.11^{\mathrm{ab}}$ & $0.06^{\mathrm{a}}$ & $0.12^{\text {bcd }}$ & $11.15^{\mathrm{ab}}$ & $2.51^{\mathrm{a}}$ & $19.09^{\mathrm{abc}}$ & $35.67^{\mathrm{ab}}$ & $45.25^{\mathrm{cd}}$ \\
\hline 2004 & & $5.01^{\mathrm{a}}$ & $4.01^{b c}$ & $1.52^{\mathrm{ab}}$ & $2.90^{\mathrm{a}}$ & $2.40^{\mathrm{abc}}$ & $0.09^{\mathrm{ab}}$ & $0.04^{\mathrm{a}}$ & $0.11^{\text {bcd }}$ & $5.30^{\mathrm{de}}$ & & $19.46^{\mathrm{abc}}$ & $37.06^{\mathrm{ab}}$ & $43.48^{\mathrm{cd}}$ \\
\hline 2005 & $3.88^{\mathrm{abc}}$ & $5.06^{\mathrm{a}}$ & $5.31^{\mathrm{abc}}$ & $1.78^{\mathrm{ab}}$ & $2.63^{\mathrm{a}}$ & $5.55^{\mathrm{abc}}$ & $0.08^{\mathrm{ab}}$ & $0.33^{\mathrm{a}}$ & $0.08^{\mathrm{cd}}$ & $4.40^{\mathrm{e}}$ & $3.70^{\mathrm{a}}$ & $18.86^{\mathrm{abc}}$ & $32.37^{\mathrm{abc}}$ & $48.78^{b c d}$ \\
\hline 2006 & $3.83^{\mathrm{abcd}}$ & $4.97^{\mathrm{a}}$ & $5.86^{\mathrm{abc}}$ & $2.07^{\mathrm{ab}}$ & $2.84^{\mathrm{a}}$ & $7.00^{\mathrm{abc}}$ & $0.14^{\mathrm{ab}}$ & $0.22^{\mathrm{a}}$ & $0.23^{\mathrm{ab}}$ & $6.90^{\text {bcd }}$ & $3.09^{\mathrm{a}}$ & $21.48^{a b c}$ & $34.46^{\mathrm{ab}}$ & $44.06^{\mathrm{cd}}$ \\
\hline 2007 & $3.82^{\mathrm{abcd}}$ & $4.84^{\mathrm{ab}}$ & $4.11^{b c}$ & $1.82^{\mathrm{ab}}$ & $2.45^{\mathrm{a}}$ & $1.35^{\mathrm{c}}$ & $0.09^{\mathrm{ab}}$ & $0.10^{\mathrm{a}}$ & $0.08^{\mathrm{cd}}$ & $5.15^{\mathrm{de}}$ & $3.14^{\mathrm{a}}$ & $19.21^{\mathrm{abc}}$ & $24.94^{\mathrm{bcd}}$ & $55.86^{\mathrm{abc}}$ \\
\hline 2008 & $3.97^{\mathrm{a}}$ & $5.01^{\mathrm{a}}$ & $3.19^{c}$ & $1.10^{\mathrm{b}}$ & $2.89^{\mathrm{a}}$ & $1.55^{\mathrm{c}}$ & $0.06^{\mathrm{b}}$ & $0.26^{\mathrm{a}}$ & $0.08^{\mathrm{cd}}$ & $3.75^{\mathrm{e}}$ & $2.02^{\mathrm{a}}$ & $18.43^{\mathrm{abc}}$ & $21.10^{\mathrm{cd}}$ & $60.32^{\mathrm{ab}}$ \\
\hline N1 & $3.72^{b c d}$ & $4.31^{b c}$ & $4.68^{b c}$ & $1.90^{\mathrm{ab}}$ & $2.81^{\mathrm{a}}$ & & $0.10^{\mathrm{ab}}$ & $0.09^{\mathrm{a}}$ & $0.06^{\mathrm{d}}$ & $9.45^{\text {abcd }}$ & $2.26^{\mathrm{a}}$ & $18.44^{b c}$ & $16.32^{\mathrm{d}}$ & $65.19^{\mathrm{a}}$ \\
\hline N2 & $3.45^{\mathrm{e}}$ & $4.06^{\mathrm{c}}$ & $5.39^{a b c}$ & $1.99^{\mathrm{ab}}$ & $1.09^{\mathrm{a}}$ & $4.95^{\mathrm{abc}}$ & $0.11^{\mathrm{ab}}$ & $0.08^{\mathrm{a}}$ & $0.06^{\mathrm{d}}$ & $10.50^{\mathrm{ab}}$ & $2.82^{\mathrm{a}}$ & $15.85^{c}$ & $15.78^{\mathrm{d}}$ & $68.38^{\mathrm{a}}$ \\
\hline
\end{tabular}

Note: Means with the different letters within columns are significantly different at 5\% between plots and secondary forests according to ANOVA and followed by a Tukeys's (HSD) test

Table 1b. Soil physico-chemical properties at rehabilitated forest and secondary forest for subsurface soil $(15-30 \mathrm{~cm})$

\begin{tabular}{|c|c|c|c|c|c|c|c|c|c|c|c|c|c|c|}
\hline \multirow{2}{*}{$\begin{array}{l}\text { Plots/ } \\
\text { Years }\end{array}$} & \multirow[b]{2}{*}{$\mathrm{pH}_{\mathrm{k}}$} & \multirow[b]{2}{*}{$\mathrm{pH}_{\mathrm{w}}$} & \multirow{2}{*}{$\begin{array}{l}\text { SOM } \\
(\%)\end{array}$} & \multirow[b]{2}{*}{ T-N } & \multirow[b]{2}{*}{ T-C } & \multirow[b]{2}{*}{ CEC } & \multicolumn{4}{|c|}{ Exchangeable cation $\mathrm{cmol}_{\mathrm{c}} \mathrm{kg}^{-1}$} & \multirow{2}{*}{$\begin{array}{l}\text { Av. P } \\
\text { (ppm) }\end{array}$} & \multicolumn{3}{|c|}{ Granule composition (\%) } \\
\hline & & & & & & & $\mathrm{K}$ & $\mathrm{Ca}$ & $\mathrm{Mg}$ & $\mathrm{Al}$ & & Clay & Silt & Sand \\
\hline 1991 & $3.82^{\text {def }}$ & $4.50^{\mathrm{bcd}}$ & $4.06^{\mathrm{a}}$ & $0.86^{\mathrm{a}}$ & $2.27^{\mathrm{a}}$ & $9.70^{\mathrm{a}}$ & & & & 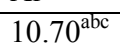 & $1.70^{\mathrm{a}}$ & & & \\
\hline 9. & $3.84^{\text {cdef }}$ & $4.69^{\mathrm{abcd}}$ & $3.14^{\mathrm{a}}$ & $5^{\mathrm{a}}$ & & & & & & & & & & \\
\hline 995 & $4.02^{\mathrm{abcd}}$ & $4.98^{\mathrm{ab}}$ & $2.66^{\mathrm{a}}$ & 0 & & $5.60^{\mathrm{a}}$ & & & & & & & & \\
\hline 96 & $4.12^{\mathrm{a}}$ & $5.06^{\mathrm{a}}$ & $1.71^{\mathrm{a}}$ & $0.62^{\mathrm{a}}$ & $a$ & $1.45^{\mathrm{a}}$ & & & $\mathrm{bc}$ & & $a^{a}$ & & & bcd \\
\hline 97 & $4.02^{\mathrm{abcd}}$ & $5.03^{\mathrm{a}}$ & $2.64^{\mathrm{a}}$ & $0.95^{\mathrm{a}}$ & $2.01^{\mathrm{a}}$ & $2.55^{\mathrm{a}}$ & $0.07^{\mathrm{a}}$ & $0.11^{\mathrm{a}}$ & $0.05^{\mathrm{bc}}$ & 5.8 & $0.95^{\mathrm{a}}$ & & & abcd \\
\hline 98 & $4.05^{\mathrm{ab}}$ & $4.83^{\mathrm{abcd}}$ & $3.09^{\mathrm{a}}$ & $1.27^{\mathrm{a}}$ & $2.03^{\mathrm{a}}$ & $4.65^{\mathrm{a}}$ & $0.09^{\mathrm{a}}$ & $0.08^{\mathrm{a}}$ & $0.06^{\mathrm{abc}}$ & & $1.16^{\mathrm{a}}$ & & & \\
\hline 99 & $3.97^{\text {abcde }}$ & $4.79^{\mathrm{abcd}}$ & $3.41^{\mathrm{a}}$ & $1.36^{\mathrm{a}}$ & $2.26^{\mathrm{a}}$ & $6.10^{\mathrm{a}}$ & $0.07^{\mathrm{a}}$ & $0.21^{\mathrm{a}}$ & $0.07^{\mathrm{abc}}$ & $6.90^{\mathrm{bcd}}$ & 2.11 & & & $a b c$ \\
\hline 00 & $3.99^{\text {abcde }}$ & $4.71^{\mathrm{bcd}}$ & $3.14^{\mathrm{a}}$ & $1.13^{\mathrm{a}}$ & $3.20^{\mathrm{a}}$ & $3.55^{\mathrm{a}}$ & $0.06^{\mathrm{a}}$ & $0.20^{\mathrm{a}}$ & $0.05^{\mathrm{bc}}$ & $7.80^{\mathrm{bcd}}$ & 2.56 & & & \\
\hline 01 & $4.03^{\mathrm{abc}}$ & $5.03^{\mathrm{a}}$ & $3.90^{\mathrm{a}}$ & $0.79^{\mathrm{a}}$ & $3.05^{\mathrm{a}}$ & $1.95^{\mathrm{a}}$ & $0 .($ & $0.11^{\mathrm{a}}$ & $0.01^{\mathrm{c}}$ & $4.20^{\mathrm{d}}$ & 1.1 & & & \\
\hline 002 & $3.78^{\text {ef }}$ & $4.89^{\mathrm{abc}}$ & $4.18^{\mathrm{a}}$ & $1.11^{\mathrm{a}}$ & $2.21^{\mathrm{a}}$ & $10.65^{\mathrm{a}}$ & $0.08^{\mathrm{a}}$ & $0.16^{\mathrm{a}}$ & $0.05^{\mathrm{bc}}$ & $11.20^{\mathrm{ab}}$ & 1.72 & $a b c$ & & \\
\hline 2003 & $3.75^{\mathrm{f}}$ & $4.75^{\mathrm{abcd}}$ & $2.30^{\mathrm{a}}$ & $0.84^{\mathrm{a}}$ & $2.54^{\mathrm{a}}$ & $7.65^{\mathrm{a}}$ & $0.07^{\mathrm{a}}$ & $0.22^{\mathrm{a}}$ & $0.07^{\mathrm{abc}}$ & $14.20^{\mathrm{a}}$ & 1.01 & $24.10^{\mathrm{abc}}$ & $a b$ & \\
\hline 2004 & $3.93^{\mathrm{abcdef}}$ & $4.94^{\mathrm{ab}}$ & $2.76^{\mathrm{a}}$ & $0.74^{\mathrm{a}}$ & $3.00^{\mathrm{a}}$ & $6.35^{\mathrm{a}}$ & $0.09^{\mathrm{a}}$ & $0.39^{\mathrm{a}}$ & $0.03^{b c}$ & $6.45^{\mathrm{bcd}}$ & 1.31 & $21.67^{\mathrm{abc}}$ & 31. & abcd \\
\hline 2005 & $3.99^{\text {abcde }}$ & $4.99^{\mathrm{ab}}$ & $3.53^{\mathrm{a}}$ & $0.99^{\mathrm{a}}$ & $2.99^{\mathrm{a}}$ & $4.10^{\mathrm{a}}$ & $0.03^{\mathrm{a}}$ & $0.60^{\mathrm{a}}$ & $0.03^{\mathrm{bc}}$ & $4.40^{\mathrm{d}}$ & 2.05 & $28.56^{\mathrm{ab}}$ & 36. & \\
\hline 2006 & $3.85^{\text {bcdef }}$ & $4.89^{\mathrm{abcd}}$ & $2.48^{\mathrm{a}}$ & $0.86^{\mathrm{a}}$ & $2.37^{\mathrm{a}}$ & $3.80^{\mathrm{a}}$ & $0.07^{\mathrm{a}}$ & $0.76^{\mathrm{a}}$ & $0.12^{\mathrm{abc}}$ & $8.70^{\mathrm{bcd}}$ & 1.61 & $24.49^{\mathrm{abc}}$ & $31.45^{\mathrm{ab}}$ & $44.06^{\mathrm{bcd}}$ \\
\hline 07 & $3.93^{\text {abcdef }}$ & $4.86^{\mathrm{abcd}}$ & $2.48^{\mathrm{a}}$ & $1.15^{\mathrm{a}}$ & $3.14^{\mathrm{a}}$ & $2.75^{\mathrm{a}}$ & $0.05^{\mathrm{a}}$ & $0.47^{\mathrm{a}}$ & $0.05^{\mathrm{bc}}$ & $5.25^{\mathrm{d}}$ & $2.28^{\mathrm{a}}$ & $23.38^{\mathrm{abc}}$ & $29.61^{\mathrm{ab}}$ & $47.02^{\mathrm{abcd}}$ \\
\hline 2008 & $4.12^{\mathrm{a}}$ & $5.00^{\mathrm{a}}$ & $1.87^{\mathrm{a}}$ & $0.44^{\mathrm{a}}$ & $2.39^{\mathrm{a}}$ & $1.30^{\mathrm{a}}$ & $0.10^{\mathrm{a}}$ & $0.20^{\mathrm{a}}$ & $0.05^{\mathrm{bc}}$ & $4.65^{\mathrm{d}}$ & 1.3 & $28.46^{\mathrm{ab}}$ & $25.79^{\mathrm{bc}}$ & $45.55^{\mathrm{bcd}}$ \\
\hline N1 & $3.89^{\text {bcdef }}$ & $4.44^{\mathrm{cd}}$ & $3.49^{\mathrm{a}}$ & $1.00^{\mathrm{a}}$ & $3.03^{\mathrm{a}}$ & $4.55^{\mathrm{a}}$ & 0.1 & $0.04^{\mathrm{a}}$ & $0.04^{\mathrm{bc}}$ & $6.90^{\mathrm{bc}}$ & & 29. & 16.9 & $53.77^{\mathrm{ab}}$ \\
\hline $\mathrm{N} 2$ & $3.75^{\mathrm{f}}$ & $4.39^{d}$ & $3.85^{\mathrm{a}}$ & $1.22^{\mathrm{a}}$ & $1.78^{\mathrm{a}}$ & $3.80^{\mathrm{a}}$ & $0.10^{\mathrm{a}}$ & $0.11^{\mathrm{a}}$ & $0.04^{\mathrm{bc}}$ & $7.25^{\mathrm{bcd}}$ & 2.12 & $25.22^{\mathrm{abc}}$ & $16.56^{\mathrm{c}}$ & $57.83^{\mathrm{a}}$ \\
\hline
\end{tabular}

Note: Means with the different letters within columns are significantly different at $5 \%$ between plots and secondary forests according to ANOVA and followed by a Tukeys's (HSD) test 
In general, the $\mathrm{pH}$ value at surface soils is higher than that of the subsurface soils. The $\mathrm{pH}(\mathrm{KCl}$ and water) of the surface soil at the study sites ranged from 3.45 to 3.99 and 4.06 to 5.06 , respectively. The soils of all plots were moderately acidic, with $\mathrm{pH}$ in water less than 5 . The $\mathrm{pH}(\mathrm{KCl}$ and water) at rehabilitated forest was significantly higher than secondary forests. According to Tan (2005), some available nutrients are deficient if soil $\mathrm{pH}$ is below 6.0. Many soil properties and processes are affected by $\mathrm{pH}$, such as clay mineral formation and microbial activity. The $\mathrm{pH}$ for both surface and subsurface soils in secondary forest was more acidic than those in the rehabilitation forest, which were associated with high exchangeable Al. The acidity occurring in the forest soils was due to the presence of $\mathrm{Al}$ and $\mathrm{H}$. According to Zaidey et al. (2010), the Al concentrations and organic matter influenced the soil acidity. Moreover, the acidity may be caused by water deficiency due to drought (Akbar et al., 2010). When this occur, root mat develop on the surface layer resulting in high carbon content. Besides, soil surface also affect the acidity since plot 1991 and plot 1993 had more forest litter compared to the rehabilitated plots.

Soil Organic Matter (SOM) is regarded as the single most important indicator of soil fertility and assessment of soil quality in the tropical regions (Paniagua et al., 1999). Soil Organic Matter (SOM) for surface soils was higher compared with that of the subsurface soils. The average SOM value for surface soil ranged from 3.19to $7.84 \%$ and for the subsurface soils it ranged from 1.71 to $4.18 \%$. The SOM for rehabilitated forest showed higher value compared to that of the secondary forests. Based on the results of this study, plot 2002 (8 years after planting) had higher organic matter content compared to the other plots for both depths (surface and subsurface soils). Carlos et al. (1991) study at Manaus, Brazil stated that soil organic matter was restored after 8 years of planting. The resultfrom this study also showed that there was low accumulation of organic matter after planting. After harvesting or clearing, organic matter from the soil decreased because of no input of organic matter from the plant since it was harvested (Akbar et al., 2010). Similar results were reported by Nye and Greenland (1964); Kedawang et al. (2004) and Ilstedt et al. (2004); soil organic matter decline rapidly after the soil is exposed due to harvesting or clearing activities. In general, the SOM in soil might increase with time because there was a visible decrease of SOM in early years and then the pool of soil carbon recovers (Nadporozhskaya et al., 2006). SOM in the surface soils was higher than the subsurface soils. According to Ishizuka et al. (1998), organic matter content was high in the surface due to the development of roots mats and accumulation of forest litter.

The value of Total Carbon (TC) was higher at surface soils compared to subsurface soils. However, the value of Total Nitrogen (TN) was higher at subsurface compared to surface soils. The TC value for surface soil ranged from 1.10 to $2.58 \mathrm{~g} \mathrm{~kg}^{-1}$ and subsurface soil ranged from 0.44 to $1.36 \mathrm{~g} \mathrm{~kg}^{-1}$. Plot 2002 gives the highest value for the surface soils among the plots. This could be due to the soils being dominated by 'resam' (Dicranopteris linearis) vegetation. Although a large supply of organic matter and its accumulation in soils can be expected in secondary forest due to its wellgrown vegetation and forest litter, the steep slope of more than $30^{\circ}$ in secondary forest as well as the high amount of rainfall throughout the year in Bintulu, Sarawak area might have caused soil erosion which resulted in the low amount of organic matter remaining in surface soil layers. According to Ishizuka et al. (2000), under a steep slope area, continuous supply of organic matter and its accumulation in the soils could not be expected.

Cation Exchange Capacity (CEC) was generally moderate for the surface soils and low for the subsurface soils throughout the rehabilitation and secondary forests. The CEC was higher for surface soils compared to subsurface soils. The highest value was at plot 2002 $\left(13.05 \mathrm{cmol}_{\mathrm{c}} \mathrm{kg}^{-1}\right)$, while the lowest was at plot 2007 $\left(1.35 \mathrm{cmol}_{\mathrm{c}} \mathrm{kg}^{-1}\right)$ for surface soils. For subsurface soils, the highest CEC was at plot 2002 and the lowest at plot 2008. These results showed that Plot 2002 had the highest organic matter contents among the rehabilitation plots. This might have affected the CEC of the soil. Moreover, the secondary forest had a different forest structure from the rehabilitation forests. Several researchers found that negative charge derived from the clay minerals affected the CEC (Ohta et al., 1993; Sakurai et al., 1998; Arifin et al., 2008a; Tanaka et al., 2007).

Exchangeable cations ( $\mathrm{K}, \mathrm{Ca}$ and $\mathrm{Mg}$ ) in surface soils were higher than those of the subsurface soils throughout the plots. The higher content of exchangeable bases in the surface is probably due to forest litter and dead plant accumulation. Soto and Diazfierroz (1993) stated that higher contents of $\mathrm{Ca}$ and $\mathrm{Mg}$ in the surface soil were due to the association of biological accumulation with biological activity and accumulation from plant. Besides, exchangeable $\mathrm{K}$ from decomposition of dead plants might be dissolved easily into the deep layer of soil because of heavy rainfall. On the other hand, Ohta and Effendi (1992) stated that subsoil may be playing an important role as a nutrient storage. They also assumed that some parts of the nutrients in the subsoil are pumped 
up slowly to the topsoil. These explain the accumulation of cations in the subsurface soils.

Exchangeable Al inhibited higher value at subsurface soils compared with surface soils for rehabilitated plots, ranging from 4.20 to $14.20 \mathrm{cmol}_{\mathrm{c}} \mathrm{kg}^{-1}$ and 3.75 to 12.30 $\mathrm{cmol}_{\mathrm{c}} \mathrm{kg}^{-1}$, respectively. According to Brown et al. (1989), exchangeable Al is higher in soils where $\mathrm{pH}$ less than 5.5 and increased with increasing depth (Akbar et al., 2010). The rehabilitated forest showed higher value of exchangeable Al compared with secondary forest for subsurface soils. Aluminum is not considered as plant nutrient and not useful for plant growth, although aluminum could be as indicator of acidity and weathering status of the soils. The toxicity of Al will restrict and disturb seedling growth (Akbar et al., 2010).

Available $\mathrm{P}$ for all plots exhibited no significant difference at $\mathrm{p}<0.05$ for both depths (surface and subsurface soils). The value of available $\mathrm{P}$ at surface soil ranged from 1.74 to $3.70 \mathrm{ppm}$ and subsurface soils ranged from 0.63 to $2.56 \mathrm{ppm}$. The concentrations of $\mathrm{P}$ in soil depends on a combination of factors including plant uptake, adsorption-desorption and dissolutionprecipitation of inorganic $\mathrm{P}$, the mineralization of organic $\mathrm{P}$ and microbial immobilization and fertilizer addition (Perrott et al., 1990; Frossard et al., 2000). However, the concentration of $\mathrm{P}$ in soils of the current study was influenced by other factors. Arifin et al. (2007) carried out a study at Kinta, Perak, Malaysia and stated that the higher clay content and exchangeable Al related to a low level of nutrients especially available phosphorus. However, the composition of forest floor also plays an important role in $\mathrm{P}$ contents. Organic matter may be a factor due to higher organic matter in the surface soil (Hirai et al., 1997; Ishizuka et al., 1998).

\subsection{Identifying the Important Soil Properties at Rehabilitated Forest in Relation to Soil Fertility}

Principal component analysis revealed six most important contributions for selected soil physicochemical properties for both depths (surface and subsurface soils) at different ages after planting (Table 2). PCA is a multivariate data set of physico-chemical properties of soil was analyzed to reduce the original complicated dimensionality and give a few principal component score that explain the variation in the data (Arifin et al., 2008b). In general, six components (PC1, PC2, PC3, PC4, PC5 and PC6) explained $78 \%$ of the total variability and each component represents a series of variables which simplifies the analysis and interpretation. The results from the surface and subsurface soils showed positive factor loading contribution in $\mathrm{PC} 1$, which were dominated by SOM, TOC, TC, CEC and exchangeable $\mathrm{Al}$ and $\mathrm{H}$. Exchangeable $\mathrm{Al}$ was in the first PC, suggesting that this cation significantly affect the soil quality in the soil ecosystem. Exchangeable $\mathrm{Al}$ can inhibit $\mathrm{Ca}$ and $\mathrm{Mg}$ uptake (De Wit et al., 2010), reduce fine root growth and lead to nutrient imbalances in the soils (Angelica et al., 2012). The PC2 is dominated by soil acidity which indicates positive loading factor for both depths and contribute to soil acidity throughout the plots. The PC3 component score for surface soils reflects granule composition, showing high positive factor loadings. In the case of PC4, CEC and $\mathrm{NH}_{4}$ contribute a positive factor loading for surface soils and subsurface soils. Available $\mathrm{P}$ gives positive factor loading for surface soils and $\mathrm{CN}$ ratio for subsurface soils for PC5. PC6 indicates a positive factor loading for $\mathrm{CN}$ ratio for surface soil and exchangeable $\mathrm{Ca}$ for subsurface soils. Thus, the information derived from the principal component analysis allows the development of simplified indicators that can represent more complex variability of soil physico-chemical properties (Arifin et al., 2008b). PCA results indicated that organic matter, total organic carbon, carbon content and cation exchange capacity have strong positive relationship which explains that the nutrients in the soil are stored in organic matter. Suitable range of relative humidity or carbon content in soil will enhance organic matter breakdown by soil microbes (Van Eekeren et al., 2008). Hence, tree roots will be able to absorb nutrients released from the organic matter for growing and maturity. Exchangeable $\mathrm{Al}$ and $\mathrm{H}$ reflect the soil acidity which reduces the availability of cations. No strong relationship was found between carbon and nitrogen for both depths, indicating that total carbon and nitrogen are at ideal ratio mineralization in the soil. CEC and clay content exhibit linear relationship and this condition proved that the clay content and CEC at ideal level for soil nutrients retention.

The results of correlation analyses among selected soil parameters are shown in Table 3. The correlation analysis between Soil Organic Matter (SOM) with Total Carbon (TC), Cation Exchange Capacity (CEC) and exchangeable Al showed positively significant difference $(p<0.05)$ for surface soils, indicating that negative charges derived from organic matter and clay minerals play important roles for cation retention capacity and soil fertility status of tropical soils as the case in this study. Ponge and Chevalier (2006) studied at Loiret, France had a positive correlation between the SOM and selected soil parameters (soil acidification and organic matter 
accumulation) which have been repeatedly observed. However, there was not strong correlation $(\mathrm{p}<0.05)$ between exchangeable $\mathrm{Al}$ with $\mathrm{TC}$ and $\mathrm{CEC}$ at surface soils. In contrast, the correlation analysis for $\mathrm{OM}, \mathrm{TC}$ and exchangeable Al with clay fraction showed proportional inverted relationship whereas correlation for CEC with clay fraction showed positive relationship. A studied by Bernier and Ponge (1994) and Aubert et al. (2004) reported that the old-growth forests reveal that soil acidification accompanies with the growth of trees influenced on the soil properties, moreover when their litter poor in nutrients and rich in secondary metabolites.

The correlation analysis for SOM and exchangeable Al showed highly positive relationship $\left(\mathrm{r}^{2}=0.623\right.$; $\mathrm{p}<0.05)$ as well as relationship for exchangeable $\mathrm{Al}$ and CEC $\left(r^{2}=0.658 ; p<0.05\right)$ for subsurface soils. The correlation between organic matter with clay fraction also exhibited directly proportional relationship but not significantly different $(\mathrm{p}<0.05)$ at subsurface soils. In contrast, correlation between $\mathrm{CEC}$ and exchangeable $\mathrm{Al}$ with clay fraction showed proportional inverted relationship but not strong correlation for both parameters, indicating the clay content affects the availability of CEC and exchangeable Al. The negative charge from the clay bond with $\mathrm{Al}$ cations, helping to reduced exchangeable $\mathrm{Al}$ (Angelica et al., 2012)

\subsection{Soil Fertility Status of Rehabilitated and Secondary Forests Using SFI and SEF}

The variations of soil properties make it difficult to find a suitable method to evaluate the soil conditions in the tropical rainforests ( $\mathrm{Lu}$ et al., 2002). Therefore, Moran et al. (2000) and Lu et al. (2002) had developed method for estimating soil fertility and site quality called Soil Fertility Index (SFI) and Soil Evaluation Factor (SEF). The assessment of soil fertility and site quality is important in forest management because it reflects to the productive capacity of the forest area to support plant growth (Arifin et al., 2008a).

Table 2. Soil parameters used for PCA and results of PCA of the rehabilitated and secondary forests

\begin{tabular}{|c|c|c|c|c|c|c|}
\hline & $\mathrm{PC} 1$ & $\mathrm{PC} 2$ & PC3 & PC4 & PC5 & PC6 \\
\hline \multicolumn{7}{|l|}{ Surface soils (0-15 cm) } \\
\hline+ & $\begin{array}{l}\text { SOM, TOC, TC, CEC } \\
\text { and exchangeable Al and } \mathrm{H}\end{array}$ & $\mathrm{pH}_{\mathrm{w}}$ and $\mathrm{pH}_{\mathrm{k}}$ & Clay and sand & $\begin{array}{l}\text { Exch. } \mathrm{K}, \mathrm{Ca} \text { and } \\
\mathrm{Mg} \text { and } \mathrm{NH}_{4}^{+}-\mathrm{N}\end{array}$ & Avai. P & CN Ratio \\
\hline- & nd & nd & exchangeable $\mathrm{Na}$ & nd & nd & $\mathrm{T}-\mathrm{N}$ \\
\hline Contribution & $\begin{array}{l}\text { Organic matter } \\
\text { constituent, CEC and acidity }\end{array}$ & Acidity & $\begin{array}{l}\text { Texture } \\
\text { and salinity }\end{array}$ & $\begin{array}{l}\text { Cation } \\
\text { retention capacity }\end{array}$ & Phosphorus & $\begin{array}{l}\text { Nitrogen } \\
\text { constituent }\end{array}$ \\
\hline Total & 4.804 & 2.877 & 2.27 & 2.064 & 1.962 & 1.725 \\
\hline Variance $(\%)$ & 24.019 & 14.387 & 11.351 & 10.321 & 9.812 & 8.623 \\
\hline Cumulative (\%) & 24.019 & 38.406 & 49.757 & 60.078 & 69.891 & 78.514 \\
\hline \multicolumn{7}{|c|}{ Subsurface soils $(15-30 \mathrm{~cm})$} \\
\hline+ & $\begin{array}{l}\text { SOM, TOC, CEC and } \\
\text { exchangeable } \mathrm{Al} \text { and } \mathrm{H}\end{array}$ & $\mathrm{pH}_{\mathrm{w}}$ & TC and Avai. P & Exch. $\mathrm{Mg}$ and $\mathrm{Na}$ & $\mathrm{CN}$ ratio & Exch. $\mathrm{Ca}$ \\
\hline- & $\mathrm{pH}_{\mathrm{k}}$ & exch. $\mathrm{K}$ and sand & nd & Clay & $\mathrm{TN}$ & $\mathrm{Nd}$ \\
\hline Contrubition & $\begin{array}{l}\text { Organic matter constituent, } \\
\text { CEC and acidity }\end{array}$ & $\begin{array}{l}\text { Soil acidity and } \\
\text { potassium content }\end{array}$ & $\begin{array}{l}\text { Carbon content } \\
\text { and phosphorus }\end{array}$ & $\begin{array}{l}\text { Cation retention } \\
\text { capacity and clay }\end{array}$ & $\begin{array}{l}\text { Nitrogen } \\
\text { constituent }\end{array}$ & $\begin{array}{l}\text { Cation } \\
\text { retention capacity }\end{array}$ \\
\hline Total & 4.957 & 2.461 & 2.456 & 2.269 & 1.709 & 1.351 \\
\hline Variance $(\%)$ & 24.784 & 12.307 & 12.282 & 11.343 & 8.546 & 6.754 \\
\hline Cumulative (\%) & 24.784 & 37.091 & 49.373 & 60.716 & 69.262 & 83.652 \\
\hline
\end{tabular}

Note: +: Factor loading with a positive value, -: Factor loading with a negative value, nd: not determined

Table 3. Relationship between selected soil properties for different depth at rehabilitated forests

\begin{tabular}{|c|c|c|c|c|}
\hline \multirow[b]{2}{*}{ Depth $0-15 \mathrm{~cm}$} & \multicolumn{4}{|l|}{$\mathrm{P}$ value $\left(\mathrm{r}^{2}\right)$} \\
\hline & $\mathrm{TC}(\%)$ & $\mathrm{CEC}\left(\mathrm{cmol}_{\mathrm{c}} \mathrm{kg}^{-1}\right)$ & Exch. Al $\left(\mathrm{cmol}_{\mathrm{c}} \mathrm{kg}^{-1}\right)$ & Clay fraction $(\%)$ \\
\hline $\mathrm{OM}(\%)$ & $0.664<0.0001 *$ & $0.602(0.0001)^{*}$ & $0.684<0.0001^{*}$ & $-0.065(0.7057)$ \\
\hline $\mathrm{CEC}\left(\mathrm{cmol}_{\mathrm{c}} \mathrm{kg}^{-1}\right)$ & $0.326(0.0521)$ & - & $0.549(0.0005)$ & $0.112(0.5168)$ \\
\hline Exch. Al $\left(\mathrm{cmol}_{\mathrm{c}} \mathrm{kg}^{-1}\right)$ & $0.543(0.0006)$ & $0.549(0.0005)$ & - & $-0.013(0.9397)$ \\
\hline \multicolumn{5}{|l|}{ Depth $15-30 \mathrm{~cm}$} \\
\hline OM $(\%)$ & $0.535(0.0008)$ & $0.451(0.0058)$ & $0.623<0.0001^{*}$ & $0.012(0.9464)$ \\
\hline $\operatorname{CEC}\left(\mathrm{cmol}_{\mathrm{c}} \mathrm{kg}^{-1}\right)$ & $0.069(0.6884)$ & - & $0.658<0.0001 *$ & $-0.315(0.0611)$ \\
\hline Exch. $\mathrm{Al}\left(\mathrm{cmol}_{\mathrm{c}} \mathrm{kg}^{-1}\right)$ & $0.125(0.4690)$ & $0.658<0.0001 *$ & - & $-0.309(0.0665)$ \\
\hline
\end{tabular}

Note: *, Significant difference $(\mathrm{p}<0.05)$ level using Pearson correlation 


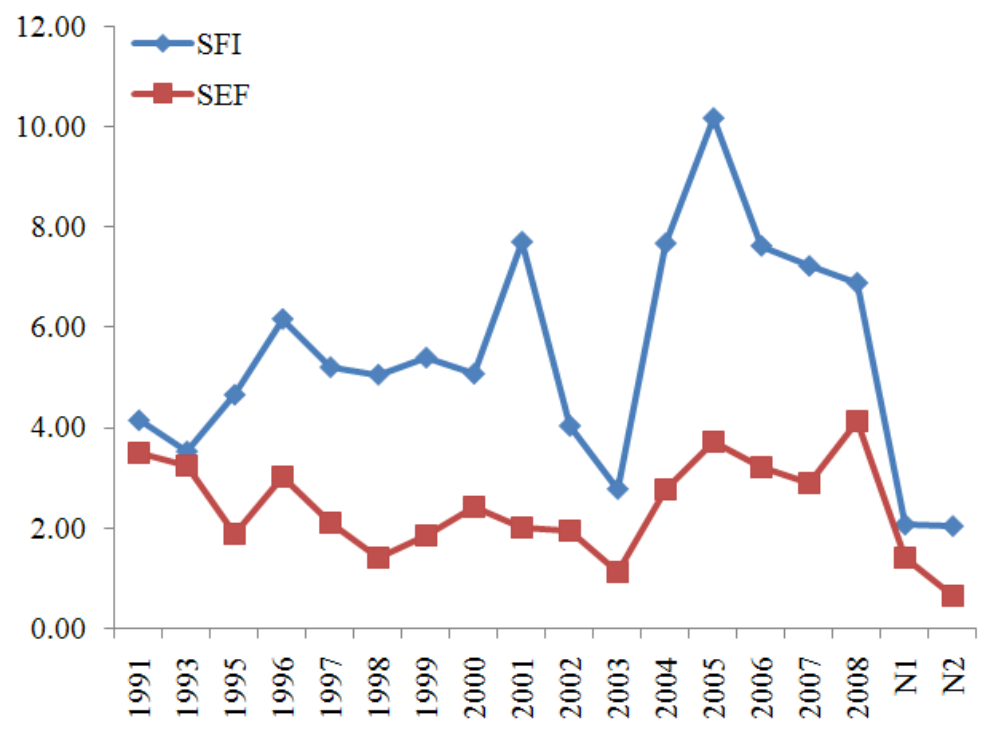

Fig. 2. Soil fertility index and soil evaluation factor between plots and secondary forest at surface soils

Doi and Sakurai (2004) also provided evidenced that SFI and SEF were applicable to estimate the soil quality and productivity under various land degradation in Northern Thailand The Soil Fertility Index (SFI) and Soil Evaluation Factor (SEF) for rehabilitation and secondary forests for surface soils are shown in Fig. 2. The result showed that SFI value was higher than SEF value at surface soils. Plot 2005 (rehabilitated forest) had the highest SFI value (10.96) among the others sites, indicating that the soil contain high soil organic matter and nutrients content derived from the 'resam' vegetation that cover the soil surface (Akbar et al., 2010). In contrast, SFI value at plot 2003 had the lowest among the plots because the surface soils covered by Imperata cylindrica and presumably due to excessive uptake of nutrient by the species. The SFI value of secondary forest had lower than rehabilitated forests, presumably the nutrient content have been continuously taken up by the mature tree associated with acidic soil with high contribution of exchangeable $\mathrm{Al}$ restricted the availability of nutrients (Wasli et al., 2011; Akbar et al., 2010; Arifin et al., 2008a).

However, the highest SEF value showed at plot 2008 (4.12), presumably that the soils contain high in soil organic matter and low in exchangeable Al. The SEF value less than five for both sites (rehabilitated and secondary forests) suggest extremely poor soil fertility (Lu et al., 2002). These means vegetation growth contributes to rapid increase in soil fertility on the soil surface. The results were similar as reported by Lu et al.
(2002). However, other factor such as climate, soil parent material and time could be also influence the soil fertility status and need to study in greater detail.

\section{CONCLUSION}

Rehabilitated and secondary forests are significantly different based on physico-chemical properties. Many plant species are adapted to acidic soils; vegetation diversity tends to decline under strongly acidic condition $(\mathrm{pH}<5)$. The availability of many plants nutrients (for example exchangeable cations and available $\mathrm{P}$ ) is strongly dependent on soil $\mathrm{pH}$. Soil organic matter is a key component of soils because of its influence on soil physical and chemical properties. Generally, exchangeable $\mathrm{Ca}$ increases with increasing $\mathrm{pH}$, while high exchangeable $\mathrm{Al}$ levels are found in soils with a $\mathrm{pH}$ below 5.2. Principal Component Analysis (PCA) indicated that organic matter, total organic carbon, carbon content and cation exchange capacity have strong positive relationship which explains that most of the nutrients are stored in surface soils. There is strong relationship between soil organic matter with total carbon, CEC and exchangeable Al. This means that soil organic matter has direct proportional relationship with TC, CEC and exchangeable Al. The SFI value was higher than SEF value for rehabilitation and secondary forests; however, the SEF value for both sites less than 5, suggesting poor soil fertility. Based on the results, it is proved that the 
rehabilitation forest is a suitable planting technique for rehabilitating of abandoned degraded shifting cultivation land. The actual time taken for rehabilitated and secondary forests to be transformed into natural forest will depend on variable environmental factors such as climate, intensity and scale of disturbance and the distance from the seed source of natural forest species.

\section{ACKNOWLEDGEMENT}

The researchers are grateful to the staff of the Department of Crop Production, Universiti Putra Malaysia, Bintulu Sarawak Campus, Department of Land Management, Faculty of Agriculture and Department of Forest Management, Faculty of Forestry, Universiti Putra Malaysia during field sampling and laboratory analysis. This study was financially supported by the Ministry of Higher Education of Malaysia (MOHE) under Fundamental Research Grant Scheme (FRGS) through Universiti Putra Malaysia, Malaysia (UPM).

\section{REFERENCES}

Arifin, A., T. Sota, J. Shamshuddin, Z. Ibrahim and D. Hatorri et al., 2007. Soil characteristics under rehabilitation of degraded forestland in Perak, Peninsular Malaysia. Pedologist, 51: 76-88.

Akbar, M.H., O.H. Ahmed, A.S. Jamaluddin, N.M. Majid and H. Abdul-Hamid et al., 2010. Differences in soil physical and chemical properties of rehabilitated and secondary forests. Am. J. Applied Sci., $\quad 7$ : 1200-1209. DOI: 10.3844/ajassp.2010.1200.1209

Alias, M.A., M.Z. Hamzah, K. Fujiwara and S. Meguro, 1998. Rehabilitation of tropical rainforests based on potential natural vegetation species for degraded areas in Sarawak, Malaysia. Tropics, 7: 223-239.

Angelica, B.C., R.F.D. Castillo, J.D. Etchevers-Barra, M.D.C. Gutierrez-Castorena and A. Baez, 2012. Selection and interpretation of soil quality indicators for forest recovery after clearing of a tropical montane cloud forest in Mexico. Forest Ecol. Manage., 277: 74-80. DOI: 10.1016/j.foreco.2012.04.013

Arifin, A., S. Tanaka, S. Jusop, N.M. Majid and Z. Ibrahim et al., 2008b. Rehabilitation of degraded tropical rainforest in Peninsular Malaysia with a multi-storied plantation technique of indigenous dipterocarp species. J. Environ., 50: 141-152.
Arifin, A., S. Tanaka, S. Jusop, N.M. Majid and Z. Ibrahim et al., 2008a. Assessment on soil fertility status and growth performance of planted dipterocarp species in Perak, Peninsular Malaysia. J. Applied Sci., 8: 3795-3805.

Aubert, M., F. Bureau, D. Alard and J. Bardat, 2004. Effects of harvesting impacts and rehabilitation of tropical rain forest (Normandy, France). Can. J. Res., 34: 233-248.

Banning, N.C., C.D. Grant, D.L. Jones and D.V. Murphy, 2008. Recovery of soil organic matter, organic matter turnover and nitrogen cycling in a post-mining forest rehabilitation chronosequence. Soil Biol. Biochem., 40: 113-121. DOI: 10.1016/j.soilbio.2008.04.010

Bernier, N. and J.F. Ponge, 1994. Humus form dynamics during the sylvogenetic cycle in a mountain spruce forest. Soil Boil. Biochem., 26: 183-220. DOI: 10.1016/0038-0717(94)90161-9

Bremner, J.M. and C.S. Mulvaney, 1982. Nitrogen-total, In: Methods of Soil Analyses, Part 2. Chemical and Mineralogical properties, Miller, R.H. and D.R. Keeney, (Eds.), American Society of Agronomy and Soil Science Society of America, Madison, WI, USA, pp; 595-624.

Brown, S., A.J.R. Gillespie and A.E. Lugo, 1989. Biomass estimation methods for tropical forests with applications to forest inventory data. Forest Sci., 35: 88-92.

Carlos, C.C., B. Volkoff and F. Andreaux, 1991. Nature and behavior of organic matter in soils under natural forest and after deforestation, burning and cultivation near Manaus. For. Ecol. Manage. 38: 247-257. DOI: 10.1016/0378-1127(91)90146-M

Cole, T.G., R.S. Yost, R. Kablan and T. Olsen, 1996. Growth potential of twelve Acacia species on acid soils in Hawaii. Forest Ecol. Manage., 80: 175-186. DOI: 10.1016/0378-1127(95)03610-5

Daljit, S.K., A. Arifin, O. Radziah, J. Shamshuddin and H. Abdul-Hamid et al., 2011. Assessing soil biological properties of natural and planted forests in the Malaysian tropical lowland dipterocarp forest. Am. J. Applied Sci., 8: 854-859. DOI: 10.3844/ajassp.2011.854.859

De Wit, H.A., T.D. Eldhuset and J. Mulder, 2010. Dissolved Al reduces $\mathrm{Mg}$ uptake in Norway spruce forest: Results from a long-term field manipulation experiment in Norway. Forest Ecol. Manage., 259: 2072-2082. DOI: 10.1016/j.foreco.2010.02.018 
Doi, R. and K. Sakurai, 2004. Principal components derived from soil physicochemical data explained a land degradation gradient and suggested the applicability of new indexes for estimation of soil productivity in the Sakaerat Environmental Research Station, Thailand. Int. J. Sustain. Dev. World Ecol., 11: 298-311. DOI: 10.1080/13504500409469833

FAO, 2010. Global forest resources assessment 2010. Food and Agriculture Organization of the United Nations.

Frossard, E., L.M. Conron, A. Oberson, S. Sinaj and J.C. Fardeau, 2000. Processes governing phosphorus availability in temperate soils. J. Environ. Q., 29: $15-23$.

Gee, G.E. and J.W. Bauder, 1986. Particle-Size Analysis. In: Methods of Soil Analysis. Part 1. Physical and Mineralogical Methods, Klute, A.E., (Ed.), Soil Science Society of America, Inc. and America Soc. Agronomy, Inc., Madison, Wisconsin, ISBN-10: 0891188118, pp: 399-404.

Grainger, A., 1993. Controlling Tropical Deforestation. 1st Edn., Earthscan, London, ISBN-10: 1853831425 , pp: 310.

Hirai, H., H. Matsumura, H. Hirotani, K. Sakurai and K. Ogino et al., 1997. Soils and distribution of Drybalanops aromatic and D. lanceolata in mixed dipterocarp forest. A case study at Lambir National Park, Malaysia. Tropics, 7: 21-33.

Ilstedt, U., A. Malmer, A. Noldgren and P. Liau, 2004. Soil rehabilitation following tractor logging: Early results on amendments and tilling in a second rotation Acacia mangium plantation in Sabah, Malaysia. Ecol. Manage., 194: 215-224. DOI: 10.1016/j.foreco.2004.02.032.

Ishizuka, S., K. Sakurai, J.J. Kedawang and H.S. Lee, 2000. Soil characteristics of an abandoned shifting cultivation land in Sarawak, Malaysia. Tropics, 10: 251-263.

Ishizuka, S., S. Tanaka, K. Sakurai, H. Hirai and H. Hirotani et al., 1998. Characterization and distribution of Soils at Lambir hills national park in Sarawak, Malaysia, with special reference to soil hardness and soil texture. Tropics, 8: 31-44.

ITTO, 2011. Status of tropical forest management. Technical Series, 38: 196-206.

Ponge, J.F. and R. Chevalier, 2006. Humus index as an indicator of forest stand and soil properties. Forest Ecol. Manage., 233: 165-175. DOI: $10.1016 /$ j.foreco.2006.06.022
Kedawang, J.J., S. Tanaka, J. Ishihara, K. Shibata and J. Sabang et al., 2004. Effects of shifting cultivation on soil ecosystems in Sarawak, Malaysia: I. Slash and burning at Balai ringin and Sabal experimental sites and effect on soil organic matter. Soil Sci. Plant Nutr., 50: 677-687. DOI: 10.1080/00380768.2004.10408524

Kobayashi, S., 1994. Effects of harvesting impacts and rehabilitation of tropical rain forest. J. Plant Res., 107: 99-106. DOI: 10.1007/BF02344536

Kuo, S., 1996. Phosphorus. In: Method of Soil Analysis. Part 3.Chemical Methods, Sparks, D.L., A.L. Page, P.A. Helmke, R.H. Leoppert and P.N. Soltanpour et al. (Eds.), Soil Science Society America, Inc. and America Soc. Agronomy, Inc., Wisconsin, ISBN-10: 0891188258, pp: 869-919.

Lamb, D. and M. Olsen, 1992. Rainforest rehabilitation trails in Subtropical Queensland, Australia. Proceedings of the International Symposium on Rehabilitation of Tropical Rain Forest Ecosystems: Research and Development Priorities, pp: 16.

Lu, D., E. Moran and P. Mausel, 2002. Linking Amazonian secondary succession forest growth to soil properties. Land Degradat. Dev., 13: 331-343. DOI: 10.1002/ldr.516

MacNamara, S., D.V. Tinh, P.D. Erskine, D. Lamb and D. Yates et al., 2006. Rehabilitating degraded forest land in central Vietnam with mixed native species plantings. Forest Ecol. Manage., 233: 358-365. DOI: 10.1016/j.foreco.2006.05.033

Miyawaki, A., 2010. Restoration of Native Forests from Japan to Malaysia. In: Restoration of Tropical Forest Ecosystem, Leith, H. and M. Lohmann (Eds.), Kluwer Academic Publishers, Netherlands, ISBN10: 9048141982, pp: 5-24.

Moran, E.F., E.S. Brondizio, J.M. Tucker, M.C.D. SilvaForsberg and S.D. McCracken et al., 2000. Effects of soil fertility and land-use on forest succession in Amazonia. Forest Ecol. Manage., 139: 93-108. DOI: 10.1016/S0378-1127(99)00337-0

Nadporozhskaya, M.A., G.M.J. Mohren, O.G. Chertov, A.S. Komarov and A.V. Mikhailov, 2006. Dynamic of soil organic matter in primary and secondary forest succession on sandy soils in The Netherlands: An application of the ROMUL model. Ecol. Model., 190: 399-418. DOI: 10.1016/j.ecomodel.2005.03.025 
Norisada, M., G. Hitsuma, K. Koroda, T. Yamanoshita, M. Masumori and T. Tange et al., 2005. Acacia mangium, a nurse tree candidate for reforestation on degraded sandy soils in the Malay peninsula. Forest Sci., 51: 498-510.

Nye, P.H. and D.J. Greenland, 1964. Changes in the soil after clearing tropical forest. Plant Soil, 21: 101-112. DOI: $10.1007 / \mathrm{BF} 01373877$

Ohta, S. and S. Effendi, 1992. Ultisols of "Lowland dipterocarp forest" in East Kalimantan, Indonesia. II. Status of carbon, nitrogen and phosphorus. Soil Sci. Plant Nutr., 39: 1-12. DOI: 10.1080/00380768.1992.10416483

Ohta, S., S. Effendi, N. Tanaka and S. Miura, 1993. Ultisols of lowland Dipterocarp forest in East Kalimantan, Indonesia: III. Clay minerals, free oxides and exchangeable cations. Soil Sci. Plant Nutr., 39 : 1-12. DOI: 10.1080/00380768.1993.10416969

Paniagua, A., J. Kammerbauer, M. Avedillo and A.M. Adrews, 1999. Relationship of soil characteristics to vegetation successions on a sequence of degraded and rehabilitated soils in Honduras. Agric. Ecosys. Environ., 72: 215-225. DOI: 10.1016/S01678809(98)00183-2

Paramananthan, S., 2000. Soils of Malaysia: Their Characteristics and Identification. 1st Edn., Academy of Sciences Malaysia, Kuala Lumpur, ISBN-10: 9839445065, pp: 616.

Mat, P.B., A.H.M. Hanif and I.M. Yusof, 1984. Report and Map of the Detailed Soil Survey of UPM Farm, Bintulu Campus, Sarawak. 1st Edn., Jabatan Pertanian, Kuching, pp: 73.

Perrott, K.W., S.U. Sarathchandra and J.E. Waller, 1990. Seasonal storage and release of phosphorus and potassium by organic matter and the microbial biomass in a high-producing pastoral soil. Aust. J. Soil Res., 28: 593-608. DOI: 10.1071/SR9900593
Sakurai, K., S. Tanaka, S. Ishizuka and M. Kanzaki, 1998. Differences in soil properties of dry evergreen and dry deciduous forests in the sakaerat environmental research station. Tropics, 8: 61-80.

Soto, B. and F. Diazfierroz, 1993. Interaction between plant ash leachates and soil. Int. J. Wildl Fire, 3: 207-216. DOI: 10.1071/WF9930207

Sumner, M.E. and B.A. Stewart, 1992. Soil Crusting: Chemical and Physical Processes. 1st Edn., Lewis Publishers, Boca Raton, ISBN-10: 0873718690, pp: 372.

Tan, K.H., 2005. Soil Sampling, Preparation and Analysis. 2nd Edn., Taylor and Francis, Boca Raton, ISBN-10: 0849334993, pp: 623.

Tanaka, S., M.E.B. Wasli, T. Kotegawa, L. Seman and J. Sabang et al., 2007. Soil properties of secondary forests under shifting cultivation by the Iban of Sarawak, Malaysia in relation to vegetation condition. Tropics, 16: 385-398.

Tilki, F. and R.F. Fisher, 1998. Tropical leguminous species for acid soils: Studies on plant form and growth in Costa Rica. Forest Ecol. Manage., 108: 175-192. DOI: 10.1016/S0378-1127(98)00225-4

Van Eekeren, N., L. Bommele, J. Bloem, T. Schouten and M. Rutgers et al., 2008. Soil biological quality after 36 years of ley-arable cropping, permanent grassland and permanent arable cropping. Applied Soil Ecol., 40: 432-446. DOI: 10.1016/j.apsoil.2008.06.010

Wasli, M.E., S. Tanaka, J.J. Kendawang, A. Abdu and J. Lat et al., 2011. Soils and Vegetation Condition of natural forests and secondary fallow forests within Batang Ai national park boundary, Sarawak, Malaysia. Kuroshio Sci., 5-1: 67-76.

Zaidey, A.K., A. Arifin, I. Zahari, A.H. Hazandy and M.H. Zaki et al., 2010. Characterizing soil properties of lowland and hill forests at Peninsular Malaysia. Int. J. Soil Sci., 5: 112-130. DOI: 10.3923/ijss.2010.112.130 